\title{
Evaluation of an enzyme immunoassay for IgM antibodies to Treponema pallidum in syphilis in man
}

\author{
F MÜLLER AND M MOSKOPHIDIS
}

From the Division of Immunology of Infectious Diseases, Department of Medical Microbiology, Institute of Hygiene, Hamburg, Federal Republic of Germany

SUMMARY An enzyme immunoassay (EIA) for the detection of immunoglobulin M.(IgM) antibodies to Treponema pallidum was investigated for specificity and sensitivity. Using the results in serum from 1192 patients with successfully treated syphilis, the assay was calculated to be about $97 \%$ specific. As in any other IgM enzyme linked immunosorbent assay (ELISA), rheumatoid factor played an important part in causing false positive results. Pre-absorption of serum with aggregated IgG was therefore necessary to perform the test. Evaluation of the results in serum from 385 patients with untreated primary, secondary, and latent syphilis as well as patients with untreated reinfections showed that the sensitivity of the assay depended on the stage of infection and varied between $98 \%$ and $93 \%$. IgM antibody titres were about ten times higher in the EIA than in the indirect immunofluorescence assay using the IgM fractions of serum. From the results it may be concluded that the EIA is an appropriate technique not only for rapid and sensitive measurement of IgM antibodies in most patients with untreated syphilis but also for selecting treponemal IgM non-reactive patients.

\section{Introduction}

Immunoglobulin M (IgM) antibodies to Treponema pallidum in the serum of patients with syphilis have been shown to be associated with the presence of virulent $T$ pallidum in the tissues of infected patients and may influence decisions regarding the need for treatment. ${ }^{1-3}$ Indirect immunofluorescence performed on serum fractions after separation of IgM from IgG, using $T$ pallidum as antigen and antihuman IgM serum labelled with fluoresceinisothiocyanate (FITC), has been considered to be the most suitable method for the detection of IgM antibodies specific to $T$ pallidum..$^{3-5}$ Separation of the IgM fraction from whole serum is preferably performed by column gel filtration or high pressure liquid chromatography. To distinguish this assay from the formerly used IgM fluorescent treponemal antibody absorbed (IgM-FTA-ABS) test in whole serum it is called the fractionated IgM-FTA-ABS or 19S(IgM)-FTA-ABS test.

The technique of an enzyme linked immunosorbent assay (ELISA) has been established for the identification of specific IgM antibodies in several

Address for reprints: Professor F Müller, Hygienisches Institut, Gorch-Fock-Wall 15/17, D-2000 Hamburg 36, West Germany

Accepted for publication 24 March 1984 virus infections ${ }^{6-8}$ or in toxoplasmosis. ${ }^{910}$ In a previous study we showed the effectiveness of an ELISA microtechnique in detecting treponemal IgM antibodies in serum from patients with untreated syphilis. ${ }^{11}$ In this report we present a TP-IgM-EIA using polystyrene beads coated with antigen and discuss its advantages.

\section{Materials and methods}

SERUM

On the basis of clinical features or history of infection (and its treatment) 1577 patients with positive results to the $T$ pallidum haemagglutination assay (TPHA) and fluorescent treponemal antibody absorbed (FTA-ABS) test were divided into: (a) those with untreated primary, secondary, or latent syphilis $(n=344)$, (b) those with treponemal reinfections ( $n=41)$, and (c) those with adequately treated syphilis $(\mathrm{n}=1192)$.

The diagnosis of primary syphilis was based on the presence of lesions (chancres) yielding positive results on dark field microscopy. All patients with secondary syphilis had a characteristic rash, with or without palmar and plantar lesions, and lymphadenitis. Those with latent syphilis were diagnosed on the basis of epidemiological studies and positive results to serology tests. Patients with reinfections 
were known to have had syphilis previously and had been successfully treated. At the time of investigation they had characteristic lesions and high titres in the treponemal and antilipoidal tests. Patients with treated syphilis were known to have been cured by adequate treatment with penicillin at least three years before investigation.

For the estimation of absorbance by the normal enzyme reaction of the TP-IgM-EIA, serum from 482 healthy blood donors giving negative reactions to the above mentioned treponemal tests served as controls.

EIA TECHNIQUE FOR IgM ANTIBODIES SPECIFIC TO $T$ PALLIDUM (TP-IgM-EIA)

The assay has been described by Yokota et $a l^{12}$ and was used quantitatively with some modifications. Polystyrene beads were coated with a purified ultrasonicate of $T$ pallidum (Nichols strain) (Fujirebio Inc, Tokyo, Japan). To $490 \mu \mathrm{l}$ of phosphate buffered saline (PBS) $(\mathrm{pH} \mathrm{7.4)} 10 \mu \mathrm{l}$ of serum were added (giving a starting dilution of $1 / 50$ ) and serial dilutions for endpoint estimation (up to $1 / 128000$ ) were performed in an absorbing buffer solution containing fragments of ultrasonicated Treponema phagedenis, biotype Reiter.

Coated beads were incubated with dilutions of serum for two hours at $37^{\circ} \mathrm{C}$ in a waterbath. After the beads were washed four times with $0.14 \mathrm{~mol} / \mathrm{l}$ sodium chloride solution they were incubated in $400 \mu \mathrm{l}$ antihuman IgM serum ( $\mu$ chain specific) labelled with horseradish peroxidase for one hour at $37^{\circ} \mathrm{C}$. After washing the beads another four times with isotonic sodium chloride solution the enzyme reaction was performed by incubation of the beads in $400 \mu \mathrm{l}$ of a substrate buffer (containing $1 \mathrm{mmol} / \mathrm{l}$ hydrogen peroxide and $0 \cdot 1 \% 2,2^{\prime}$-azino-di-ethylbenzothiazoline-6-sulphonate) for one hour at $37^{\circ} \mathrm{C}$ in the dark. Then the reaction was stopped by the addition of $2 \mathrm{ml} 0.05 \mathrm{~mol} / \mathrm{l}$ oxalic acid. The adsorbance was read at $420 \mathrm{~nm}$ in $250 \mu \mathrm{l}$ of the specimens using a Titertek Multiscan MC (Flow Laboratories, McLean, Virginia, USA).

Optical densities in the several serum dilutions which exceeded the arithmetic mean plus its fivefold standard deviation $(\overline{\mathrm{x}}+5 \mathrm{~s})$ of at least eight negative controls (with appropriate serum concentration) were considered to be positive.

\section{TECHNIQUE OF FRACTIONATED IgM-FTA-ABS} TEST

Separation of IgM from IgG antibodies in serum was carried out by Ultrogel AcA 34 filtration. ${ }^{5}$ Briefly, $0.7 \mathrm{ml}$ unheated serum was filtrated through a gel column $(1.5 \times 14 \mathrm{~cm})$ using PBS $(\mathrm{pH} 7 \cdot 3)$. Fractions of $1.3 \mathrm{ml}$ were collected, and the absorb- ance at $280 \mathrm{~nm}$ was measured. To show IgM antibodies specific to $T$ pallidum in the fractions, $T$ pallidum (Nichols strain) was used as antigen. An antihuman IgM serum ( $\mu$ chain specific) labelled with FITC was used in a working dilution of 1/50 (Daco Immunochemicals, Copenhagen, Denmark).

\section{TP-IgM-EIA TEST IN FRACTIONS AFTER GEL} FILTRATION OF SERUM

In the fractions of serum from 25 patients with untreated secondary syphilis the TP-IgM-EIA test was performed quantitatively on the IgM as well as on the IgG eluates, starting with undiluted fractions.

\section{MEASUREMENT OF TOTAL IgM AND IgG IN FRACTIONS}

IgM and IgG were measured by single radial immunodiffusion using Partigen plates (Behringwerke, Marburg, West Germany).

\section{ABSORPTION OF SERUM BY AGGREGATED HUMAN IgG}

Equal amounts of a suspension of latex particles coated with IgG (Behringwerke, Marburg, West Germany) and undiluted serum were shaken for 30 minutes at $22^{\circ} \mathrm{C}$. Then the particles were removed by high speed centrifugation, resulting in a serum dilution of $1 / 2$.

\section{Results}

\section{SPECIFICITY OF TP-IgM-EIA TEST}

Serum specimens from 1192 patients with adequately treated syphilis were investigated to estimate the specificity of the assay. Of these, 1152 gave negative results in both the TP-IgM-EIA and the fractionated IgM-FTA-ABS tests. In 40 serum samples from this group of patients, the TP-IgM-EIA gave positive results at a serum dilution of $1 / 50$ whereas the fractionated IgM-FTA-ABS test gave negative results at a serum dilution of $1 / 5$. These data give an assay specificity of $96.6 \%(1152 \times 100 / 1192)$.

Figure 1 shows the treponemal IgM specificity of the assay. The titres of treponemal IgM antibodies in the fractions after gel filtration of a representative serum sample from a patient with untreated secondary syphilis are completely parallel in the TPIgM-EIA and the fractionated IgM-FTA-ABS test and correspond with total IgM. No TP-IgM-EIA reaction was observed in those fractions containing IgG antibodies specific to $T$ pallidum.

INFLUENCE OF RHEUMATOID FACTOR ON

SPECIFICITY OF TP-IgM-EIA TEST

In serum from 38 patients a rheumatoid factor with titres between $1 / 160$ and $1 / 2560$ (estimated by use of 


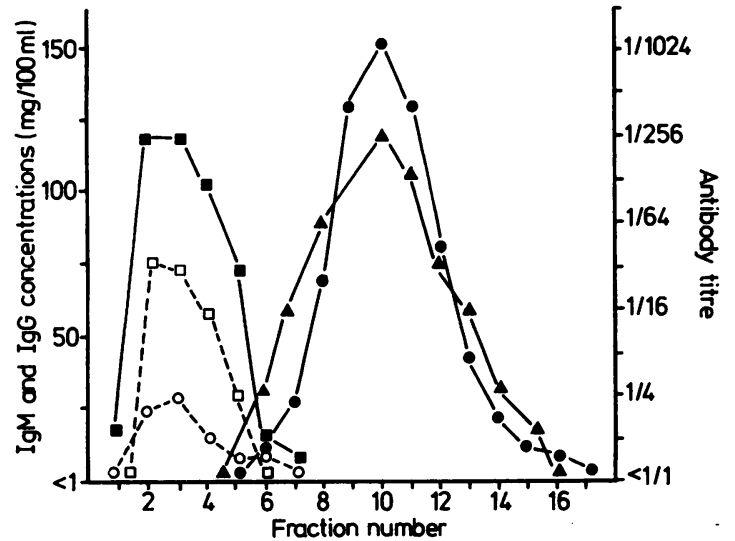

FIG 1 IgM and IgG antibodies to $T$ pallidum in fractions after gel filtration of serum from patient with secondary syphilis:
IgM-FTA-ABS test
TP-IgM-EIA test
Concentration of total IgM
- IgG-FTA-ABS test
- Concentration of total IgG.

the rheumatoid antibody haemagglutination assay (RAHA)) was found together with IgG antibodies specific to $T$ pallidum (shown by the IgG-FTA-ABS test) but no IgM antibodies specific to T pallidum (in the fractionated IgM-FTA-ABS test). In 26 of these 38 serum samples containing rheumatoid factor the TP-IgM-EIA test gave false positive and finally negative reactions when the serum samples were reinvestigated after absorbance with latex particles coated with IgG.

SENSITIVITY OF TP-IgM-EIA TEST

The sensitivity of the assay was estimated in relation to the stage of infection and the results of the fractionated IgM-FTA-ABS test. The table summarises our findings in serum samples from 385 untreated patients with syphilis. Whereas there was high sensitivity in serum from patients with primary and secondary syphilis $(97 \cdot 3 \%$ and $98 \cdot 0 \%$ respectively) sensitivity was lower in serum from patients with latent syphilis $(93 \cdot 3 \%)$ and with reinfection
$(92 \cdot 7 \%)$. In the same groups of patients the mean sensitivity of the fractionated IgM-FTA-ABS test was $\mathbf{9 8 \cdot 7 \% \text { . }}$

In eight patients with clinical symptoms of syphilis and high titres of IgG antibodies specific to $T$ pallidum (TPHA-IgG titre $\geqslant 1 / 20480$ ) the TP-IgMEIA test as well as the fractionated IgM-FTA-ABS test gave negative results at all dilutions used.

A prozone phenomenon was observed in nine patients. In these serum samples, which also had high titres of IgG antibodies specific to $T$ pallidum, the TP-IgM-EIA gave negative results at the starting dilution of $1 / 50$ but became positive at a serum dilution of $1 / 100$ or more.

\section{COMPARISON OF ANTIBODY TITRES DETECTED} BY THE TP-IgM-EIA AND THE FRACTIONATED IgM-FTA-ABS TESTS

Figure 2 shows IgM antibody titres obtained with the TP-IgM-EIA test plotted against those obtained with

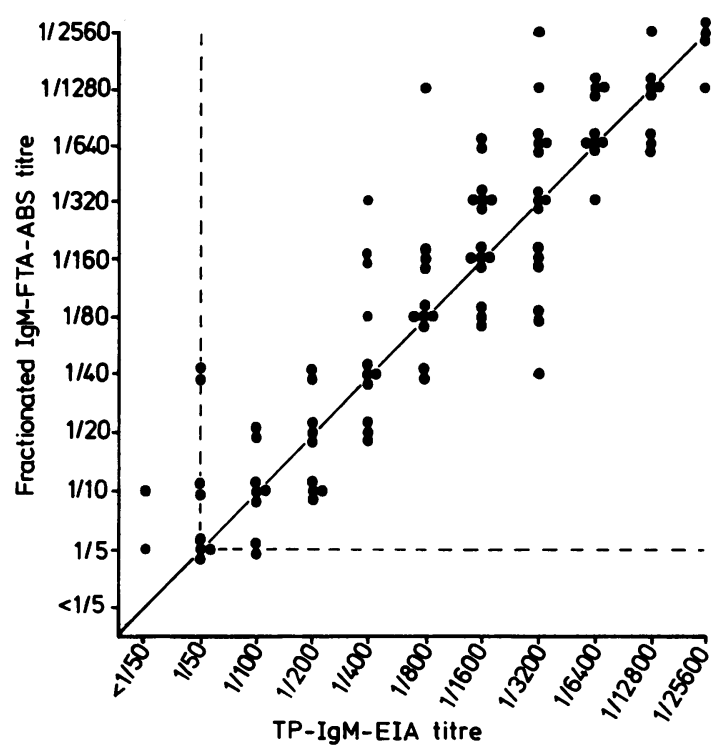

FIG 2 Comparison of titres from fractionated IgM-FTA$A B S$ test and TP-IgM-EIA test $(n=102)(\ldots$ borderline of specificity of the tests).

TABLE Sensitivity of TP-IgM-EIA test compared with 19S(IgM)-FTA-ABS test at different stages of untreated syphilis

\begin{tabular}{lllll}
\hline & \multicolumn{2}{l}{ No of patients with positive results to: } & \multicolumn{1}{c}{$\begin{array}{l}\text { Sensitivity } \\
\text { of TP-IgM-EIA } \\
\text { test (\%) }\end{array}$} \\
\cline { 2 - 5 } Stage of infection & Both tests & $\begin{array}{l}\text { l9S(IgM)-FTA-ABS } \\
\text { test only }\end{array}$ & $\begin{array}{l}\text { TP-IgM-EIA } \\
\text { test only }\end{array}$ & $97 \cdot 3$ \\
\hline Primary $(\mathrm{n}=74)$ & 72 & 2 & 0 & $98 \cdot 0$ \\
Secondary $(\mathrm{n}=150)$ & 145 & 3 & 2 & $93 \cdot 3$ \\
Latent $(\mathrm{n}=120)$ & 110 & 8 & 2 & $92 \cdot 7$ \\
Reinfection $(\mathrm{n}=41)$ & 37 & 3 & 1 & \\
\hline
\end{tabular}


the fractionated IgM-FTA-ABS test. In 87 of 102 serum samples from patients with untreated syphilitic infection the TP-IgM-EIA titres were, within the limit of technical error, 10 times higher than those of the fractionated IgM-FTA-ABS test.

\section{Discussion}

An enzyme immunoassay for the detection of IgM antibodies specific to $T$ pallidum in the serum of patients with syphilis and for the exclusion of these antibodies in adequately treated patients must offer diagnostic certainty when recommended for serological diagnosis of treponemal infections. Unlike in viral or parasitic infections, positive or negative results to an IgM assay for syphilis may influence the decision about whether the patient needs specific treatment or not. The desired information can only be gained by an assay with high specificity and sensitivity, which should also be easy to perform and read.

The TP-IgM-EIA test described here seems to fulfil these preconditions. Using polystyrene beads coated with purified antigens of $T$ pallidum (Nichols strain), the enzyme reaction of non-specific control serum at $420 \mathrm{~nm}$ resulted in an absorbance of $<0 \cdot 100$ at $1 / 50$, the starting dilution of the test. The specificity of the assay was calculated to be about $97 \%$. This is in the same range as that of the fractionated IgM-FTA-ABS test $(97 \cdot 6 \%)^{13}$ and the microenzyme linked immunosorbent assay for IgM antibodies specific to $T$ pallidum $(97 \cdot 5 \%) .{ }^{11}$ No reaction occurred within the fractions of the IgG elution peak of serum from a patient with untreated secondary syphilis containing IgG antibodies of high titre specific to $T$ pallidum (fig 1 ). Concerning the assay specificity, it should be emphasised that preabsorption of serum with aggregated human IgG is of great importance because rheumatoid factor, possibly present in the serum, must be removed. For routine purposes it is sufficient to reinvestigate positive serum comparatively before and after absorption with latex particles coated with IgG to identify interference by rheumatoid factor.

The sensitivity of the assay depends on the stage of the untreated infection and was calculated to be $\mathbf{9 7 . 3 \%}$ for primary and $\mathbf{9 8 \%}$ for secondary syphilis. The lower sensitivity (about 93\%) in serum from patients with latent syphilis or reinfection with $T$ pallidum might be explained by a competition between high IgG and lower IgM antibody concentrations.

In $2 \cdot 1 \%$ of the patients with characteristic symptoms of syphilis who had not been treated and who had high titres of IgG antibodies specific to $T$ pallidum, we found negative results to both the TP-
IgM-EIA and the fractionated IgM-FTA-ABS tests. It is well known that high IgG antibody serum concentrations can induce an in vivo suppression of the IgM antibody response, ${ }^{14}$ and Uhr and Möller reviewed published reports of this. ${ }^{15}$ Our observation of negative reactions to both assays might be explained by this in vivo suppression mechanism.

An in vitro prozone phenomenon was observed in $2 \cdot 3 \%$ of untreated patients with syphilis. In contrast to former recommendations, ${ }^{12}$ it is necessary to perform the TP-IgM-EIA quantitatively-that is, at least at dilutions of $1 / 50,1 / 500$, and $1 / 1000$.

Whereas the sensitivity of both the TP-IgM-EIA and the fractionated IgM-FTA-ABS tests was in the same range, the antibody fixing capacity of the TPIgM-EIA was about 10 times higher than that of the fractionated IgM-FTA-ABS test and the microenzyme linked immunosorbent assay for IgM antibodies. It is therefore possible to estimate very low titres of IgM antibody specific to $T$ pallidum not only in serum but also in the cerebrospinal fluid.

Hunter et al have stated that enzyme immunoassays will become sufficiently sensitive and specific to replace other treponemal tests. ${ }^{16}$ From our experience with the TP-IgM-EIA we recommend the assay for confirmation of the results of other tests for IgM specific to $T$ pallidum. It should be considered whether this assay can replace the sophisticated IgMFTA-ABS test in serum fractions after gel filtration.

\section{References}

1. Herbst B-R, Goerz G, Müller F. Diagnostic and therapeutical effectiveness of the IgM-FTA-ABS and the IgM-FTA-19S test in syphilis. Aktuelle Dermatologie 1975; 5: 175-83.

2. Müller F, Oelerich S. Correlation of immunological parameters to the stages of apparent and latent syphilis. Dermatol Monatsschr 1979; 165:385-95.

3. Müller F, Lindenschmidt E-G. Demonstration of specific 19S(IgM) antibodies in untreated and treated syphilis. $\mathrm{Br} J$ Vener Dis 1982;58:12-7.

4. Moskophidis M, Müller F. Molecular analysis of immunoglobulin $M$ and $G$ immune response to protein antigens of Treponema pallidum in human syphilis. Infect Immun 1984; 43: 127-32.

5. Müller F. The 19S(IgM)-FTA-ABS test in the serodiagnosis of syphilis. Immun Infekt 1982;10:23-34.

6. Duermeyer W, van der Veen J. Specific detection of IgM antibodies by ELISA, applied in hepatitis. Lancet 1978; ii:684-5.

7. Roggendorf M, Deinhardt F, Frössner GG, Scheid G, Bayer $B$, Zachoval $R$. Immunoglobulin $M$ antibodies to hepatitis $B$ core antigen: evaluation of enzyme immunoassay for diagnosis of hepatitis B virus infection. J Clin Microbiol 1981;13:618-25.

8. Ziegelmaier R, Behrens F, Enders G. Class-specific determination of antibodies against cytomegalo (CMV) and rubella virus by ELISA. J Biol Stand 1981;9:23-33.

9. Camargo ME, Ferreira AW, Mineo JR, Takiguti CK, Nakahara OS. Immunoglobulin $\mathbf{G}$ and immunoglobulin $\mathbf{M}$ enzyme-linked immunosorbent assay and defined toxoplasmosis serological patterns. Infect Immun 1978; 21:55-8.

10. Naot Y, Remington JS. An enzyme-linked immunosorben assay for detection of IgM antibodies to Toxoplasma gondii: use for diagnosis of acute acquired toxoplasmosis. J Infect Dis 1980; 142: 757-66. 
11. Lindenschmidt EG, Laufs R, Müller F. Microenzyme-linked immunosorbent assay for the detection of specific IgM antibodies in human syphilis. Br J Vener Dis 1983;59:151-6.

12. Yokota M, Kasahara Y, Tsuji Y, Kobayashi M, Tomizawa T. The measurement of IgG and IgM antibodies to Treponema pallidum by enzyme-linked immunosorbent assay (ELISA) simultaneously. In: E Levy, ed. Advances in pathology. Vol 1. Oxford and New York: Pergamon Press, 1982:125-8.

13. Müller F. Immunological and laboratory aspects of treponematoses. Dermatol Monatsschr 1984; 170:357-66.
14. Araujo FG, Remington JS. IgG antibody suppression of the IgM antibody response to Toxoplasma gondii in newborn rabbits. J Immunol 1975; 115: 335-8.

15. Uhr JW, Möller G. Regulatory effect of antibody on the immune response. Advances in Immunochemistry 1968;8: 81-127.

16. Hunter EF, Farshy CE, Liska SL, Cruce DD, Crawford JA Feeley JC. Sodium desoxycholate-extracted treponemal antigens in an enzyme-linked immunosorbent assay for syphilis. J Clin Microbiol 1982; 16:483-6. 